\title{
Analysis of the reasons for the resettlement of Western Siberia in the context of sustainable development
}

\author{
Nataliya Levochkina ${ }^{1,}{ }^{*}$, Alexander Zinchenko ${ }^{2}$ \\ ${ }^{1}$ K.G. Razumovsky Moscow State University of Technologies and Management (the First Cossak \\ University), Moscow, st. Zemlyanoyval, 73, Omsk, Kujbysheva Str., 79, Russia \\ ${ }^{2}$ Federal State Budgetary Educational Institution "Omsk State University named after F. M. \\ Dostoevsky", Omsk, Russia
}

\begin{abstract}
The construction of a new railway is considered as a way to successfully solve many socio-economic problems of regional significance, the development of regional production complexes (in particular, petrochemical), the transfer of the center of gravity from the South of Western Siberia, where the reserves of ecological capacity are almost exhausted, to the regions of the Near North, where such reserves are available. The authors note that this will create real prerequisites for expanding the main settlement zone within Western Siberia at the expense of the Near North, eliminating the "Irtysh settlement gap".
\end{abstract}

\section{Introduction}

The problems of further development and improvement of the Russian resettlement system remain highly relevant. First of all, this applies to the regions of Asian Russia (Siberia and the Far East), the formation of settlement structures of which is still very far from being completed.

Each of the two main zones that make up the Russian population settlement system has its own set of not only quantitative, but also qualitative features. For the settlement system of the "main strip", it can be noted: - the continuous nature of settlement almost throughout its territory: the distances between neighboring settlements rarely exceed 15-20 km, their zones of influence intersect and form a single array; 15-the emergence of a linear-cellular structure in the form of a stable supporting frame of settlement - a system of large citiesnodes connected by communication lines (transport network of all types) [7]. The Northern zone, on the contrary, is characterized by a focal, discrete settlement, which does not allow us to speak of the settlement system as a single coherent structure. The basic framework of settlement here exists, but is in the stage of its formation, its presence is indicated by the increased population density along the main transport routes [8].

First of all, they need a significant further development of the settlement system of Eastern Siberia and the Far East. Within their borders, there is practically no continuous

\footnotetext{
*Corresponding author: natnaukaomsk@mail.ru
} 
band of resettlement. There are significant gaps between the areas of a relatively dense population. The line of continuous and relatively dense resettlement runs only along the Trans-Siberian (Main Siberian) railway (hereinafter-the Trans-Siberian Railway). This circumstance determines the existence of many geopolitical and geo-economic problems that require an effective and early solution [1].

In this regard, the situation is somewhat better in Western Siberia, more precisely within its southern half - the South Siberian macroregion (according to the" Strategy of Spatial Development of the Russian Federation for the period up to 2025", this macroregion includes the Omsk, Novosibirsk, Tomsk and Kemerovo regions, the Altai Territory and the Altai Republic) [2].

A relatively developed resettlement zone was formed here, including the territories of the Kemerovo Region and the Altai Territory, the eastern half of the Novosibirsk and southern Tomsk regions. Within this area, almost everywhere, the population density does not fall below the value of 10 people per 1 sq.km, reaching an average of 20 people per 1 sq.km (Fig. 1). This makes it possible to attribute this area (the Kuznetsk-Altai Land) to the main zone of settlement of Russia as a whole.

But the problem is that the Kuznetsk-Altai land has a very conditional connection with the main band of resettlement of the European and Ural regions of the country by means of a very narrow band of settlement (almost a line) with the corresponding indicators of population density along the Trans-Siberian Railway within the south of the Omsk and Tyumen regions (Fig. 1). We can say that this circumstance determines the "bottleneck" (literally and figuratively) in the settlement system of our macroregion (it can be called the "Irtysh settlement gap", since for the most part it stretches along the Irtysh and its tributaries).

\section{Results and discussion}

At the moment, there are still significant disparities in the resettlement system and in Western Siberia as a whole. The most developed settlement structure was formed in the south of the district within its forest-steppe and steppe natural zones, mainly along the Trans-Siberian Railway.

In the southern regions of Western Siberia (the Kemerovo Region, the Altai Territory, the Altai Republic, the southern parts of the Novosibirsk, Omsk, Tomsk and Tyumen regions), which occupy less than $30 \%$ of its territory, more than $80 \%$ of the population of our district lives. The population density index here, according to our calculations, exceeds 15 people per square $\mathrm{km}$. Accordingly, in the northern regions of Western Siberia, which occupy more than $70 \%$ of its territory, about $20 \%$ of the population lives, the density of which is less than 2 people per square $\mathrm{km} \mathrm{[3].}$

In addition, another significant disparity is revealed in the resettlement structure of Western Siberia. If we consider separately the pattern of colonization of the Northern regions, here the relative development has now reached the resettlement system of the regions of the Middle of the North within the Khanty-Mansi Autonomous district and the North-West territory of the Tomsk region (district of the city of Swan) (Fig.1). The average population density in the Middle of the North is, according to our calculations, the 2.5 people per sq. km [3]. 


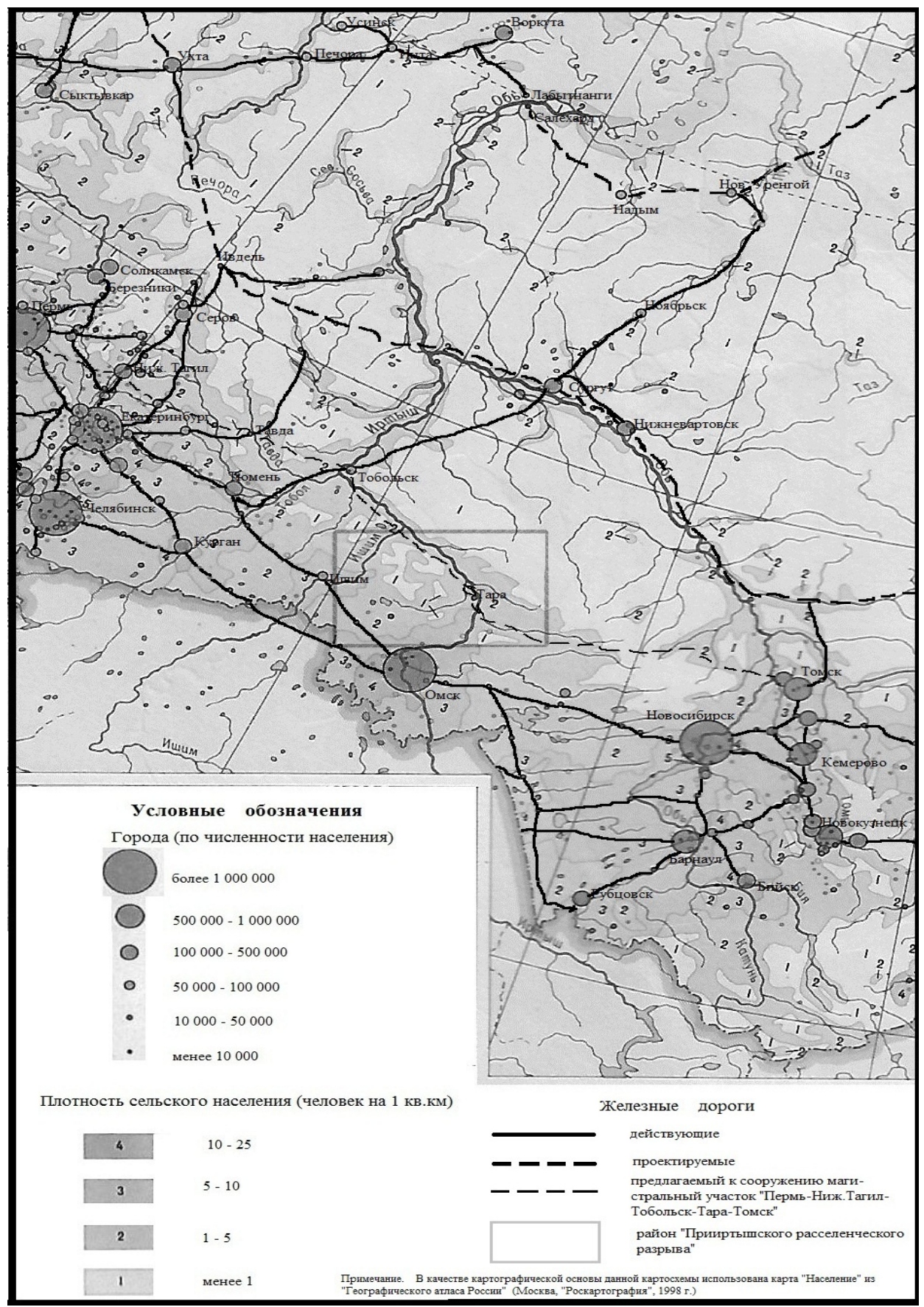

Fig. 1. Map diagram of the settlement system of Western Siberia.

The system of resettlement of the regions of the Near North, which include the northern half of the Tyumen Region (Tobolsk, Uvatsky, Vagaysky and Vikulovsky districts), the north of the Omsk (Ust-Ishim, Tevrizsky, Znamensky, Tarsky, Sedelnikovsky, Kolosovsky, Muromtsevsky and Bolsheukovsky districts) and Novosibirsk (Kyshtovsky, Ust-Tarksky, Vengerovsky and Northern districts) regions, as well as almost the entire territory of the 
Tomsk Region with the exception of the extreme northwest (Alexandrovsky district) and the south-east (Tomsk and Kozhevnikovsky districts), less developed, population density here, according to our calculations, it does not reach even 1.6 people per square $\mathrm{km} \mathrm{[3].}$

At the same time, the regions of the Near North have more favorable natural and climatic conditions compared to the regions of the Middle North. Agricultural production, including crop production, has developed quite well here. The cessation of the outflow of rural population and the growth of urban resettlements could contribute to the expansion of the main resettlement zone of Western Siberia at the expense of the regions of the Near North.

The insufficient degree of population in the Near North currently determines the low level of development of productive forces here, which, in turn, has as a consequence the underutilization of natural resource potential, as well as the extension of communications within Western Siberia. This significantly increases unproductive costs in the economy of the region, primarily transport costs.

At the same time, it should be noted that this problem is currently not only not solved, but also escalates. There is a significant outflow of population from the northern regions of the Omsk region, which also provide a link between the resettlement systems of the European part of Russia and the Urals and the Kuznetsk-Altai land, and the "Irtysh settlement gap" is becoming more pronounced.

Why is there a degradation of the resettlement system of the Omsk region? In our opinion, the main reason for the development of this process is the insufficient level of transport development in its northern regions. This negatively affects the quality of life of the local population (both urban and rural), determines the impossibility of developing most of the heavy industries here and the low efficiency of light and food industry enterprises, which objectively reduces economic activity and exacerbates the problem of employment.

Due to the lack of effective transport links with the neighboring districts of the Tomsk and Tyumen regions, in the north of our region, interregional economic ties are practically not developing, which could provide a significant expansion of the markets for the products of local enterprises (primarily the food industry).

For a long time, there has been talk about the construction of the Tobolsk-Tara-Tomsk highway, which will provide a direct and efficient transport connection between the northern districts of the Omsk Region and the neighboring districts of the Tyumen and Tomsk regions. In July 2018, as part of the visit to the Omsk region of the Minister of Transport of the Russian Federation, Ye. Dietrich confirmed the need for the construction of this very important infrastructure facility for the economy of several regions. However, it has not yet started.

However, in our opinion, only the construction of this highway through these areas is not enough to form a developed resettlement structure here. In Siberian conditions, the only mode of transport that provides all-season, reliable and efficient transport communication is the railway. The construction of new railway lines here will create favorable conditions for the development of heavy industry in local settlements and, accordingly, the growth of the urban population.

The "Message of the President of the Russian Federation to the Federal Assembly" of March 1, 2018 and the Decree of the President of the Russian Federation of May 7, 2018 state the need to modernize and expand the main infrastructure of the country, providing for the development of the transport corridors "West-East" and "North-South" for the transport of goods by 2024, as well as to increase the level of economic connectivity of the country through the expansion and modernization of railway, aviation, road, sea and river infrastructure $[4,5]$. 
These goals are also defined as the main guidelines in the National Project "Comprehensive Plan for the modernization and expansion of the main infrastructure for the period up to 2024" Section 1. Transport Infrastructure" and the Federal Project (within the framework of the above-mentioned National Project) "Railway Transport and Transit" [6].

To achieve these goals, these state documents set a number of specific tasks, in particular: increasing the capacity of the Baikal-Amur and Trans-Siberian Railways by one and a half times until 2024, up to 180 million tons per year; forming nodal cargo multimodal transport and logistics centers; reducing the time for transporting containers by rail from the Far East to the western border of Russia to seven days [4 - 6].

These are very large-scale and complex tasks, and their solution will require maximum effort and resources at both the federal and regional economic levels. At the same time, their solution will ensure not only the achievement of national goals, but also the satisfaction of regional economic interests, primarily, increasing the degree of transport development of the territory.

Attempts to solve these problems have been made before. In particular, in order to increase the capacity of the Trans-Siberian Railway, the formation of cargo multimodal transport and logistics centers has begun in Novosibirsk, Yekaterinburg and other transport hubs along it, and the construction of a railway bypass of the Omsk transport hub is planned. However, due to the rapid growth of domestic and international transit freight traffic in the West-East direction, these measures to increase the carrying capacity of the Trans-Siberian Railway may not be enough. In all likelihood, it is necessary to build an effective backup of the main course of the Trans-Siberian Railway.

\section{Conclusions}

In our opinion, such a stand-in could be the railway line of the latitudinal direction "PermNizhny Tagil-Tobolsk-Tara-Tomsk" (Fig.1). It will provide a more efficient transit of goods and passengers on the Trans-Siberian Railway from the Urals to Krasnoyarsk, as this route is shorter than the current one. In addition, the new Transsib stand-in will allow you to bypass the most congested transport hubs on the Transsib - Yekaterinburg, Omsk and Novosibirsk.

This provides this project with significant advantages over others in terms of solving the problem of the federal level - a significant increase in the capacity of the Trans-Siberian Railway within Western Siberia.

At the same time, the construction of a new railway line along the proposed route will contribute to the successful solution of many socio-economic problems of regional significance - more effective development of regional production complexes (in particular, oil and gas chemical), transfer of the center of gravity in the development of environmentally intensive industries from the South of Western Siberia, where the reserves of ecological capacity are almost exhausted, to the regions of the Near North, where such reserves are available, and creation of real prerequisites for the expansion of the main zone of settlement within Western Siberia at the expense of the regions of the Near North, elimination of the «Irtysh settlement gap».

\section{References}

1. V. V. Kuleshov, Siberia and the Center: the balance of interests, 1, (1998)

2. Strategy of spatial development of the Russian Federation for the period up to 2025 (2021). Access mode: 
https://www.economy.gov.ru/material/directions/regionalnoe razvitie/strategicheskoe planirovanie prostranstvennogo razvitiya/

3. G. Zinchenko, Problemy sovershenstvovaniya sistemy rasseleniya Zapadnoy Sibiri, 8 (2006)

4. Message of the President of the Russian Federation to the Federal Assembly (2018). Access mode: http: / /kremlin.ru/ events/ president/ news/56957

5. Decree of the President of the Russian Federation (2018). Access mode: http://www.kremlin.ru/acts/bank/43027

6. National project "Comprehensive plan for the modernization and expansion of the main infrastructure for the period up to 2024". Access mode: https://www.itpgrad.ru

7. G. M. Lappo, Itogi i perspektivy rossijskoj urbanizacii (2005)

8. V. R. Bashirov, Sovershenstvovanie metodiki kartografirovanija sistemy rasselenija naselenija Rossii (2017)

9. A. Konstantinov, S. Loiko, A. Kurasova, E. Konstantinova, A. Novoselov, G. Istigechev, S. Kulizhskiy, First findings of buried late-glacial paleosols within the dune fields of the tomsk priobye region (se western siberia, russia), Geosciences, 9 (2019)

10. M. K. Rogachev, V.V. Mukhametshin, L.S. Kuleshova, Improving the efficiency of using resource base of liquid hydrocarbons in jurassic deposits of western Siberia, Journal of Mining Institute, 240 (2019)

11. M. Rudmin, A. Mazurov, S. Banerjee, Origin of ooidal ironstones in relation to warming events: Cretaceous-eocene bakchar deposit, south-east western Siberia, Marine and Petroleum Geology, 100 (2019)

12. N. E. Ryabogina, A. S. Afonin, S. N. Ivanov, H. Li, P. A. Kalinin, S. N. Udaltsov, S. A. Nikolaenko, Holocene paleoenvironmental changes reflected in peat and lake sediment records of western siberia: Geochemical and plant macrofossil proxies, Quaternary International, 528 (2019) 